ACTA THERIOLOGICA

Vol. 25, 3: $31-38,1980$

\title{
Notes on the Reproduction and Postnatal Development of the Forest Shrew
}

\author{
R. M. BAXTER \& C. N. V. LLOYD
}

Baxter R. M. \& Lloyd C. N. V., 1980: Notes on the reproduction and postnatal development of the forest shrew. Acta theriol., 25, 3: 31-38

The reproduction and postnatal development of the forest shrew Myosorex varius ( $\mathrm{S} \mathrm{muts}, 1832$ ) was studied in captive specimens and from trapping records. The breeding season lasts from September to March and females exhibit a post-partum oestrus. The mean litter size is 2.9 with the young weighing $1 \mathrm{~g}$ at birth. Initially the young nipplecling but later change to caravanning. All the young were weaned by Day 25. The significance of nipple-clinging as a precursor to caravanning is discussed.

[Dept. Zool., Univ. Natal, P.O. Box 375, Pietermaritzburg 3200, Natal, South Africa].

\section{INTRODUCTION}

Myosorex varius is a monotypic species ( $\mathrm{Heim}$ de $\mathrm{Bals}$ a c \& M e ester, 1977) ranging from Mariepskop, eastern Transvaal in the north, westwards as far as Koster, southwards through Zululand, Natal, Lesotho and along the coast of the Cape Province as far as Port Nolloth on the west coast ( $\mathrm{M}$ e e st e r, 1958). In the Transvaal it ranges in size from $100-135 \mathrm{~mm}$ total length and $7-19 \mathrm{~g}$ in mass $(\overline{\mathrm{x}}=11.4 \mathrm{~g})$ with no sexual dimorphism ( $\mathrm{R}$ a u t e $\mathrm{n} \mathrm{b}$ a $\mathrm{ch}, 1978$ ). Specimens from around Pietermaritzburg tend to be slightly larger than those from the Transvaal (B a x t e r et al., in prep.).

Numerous specimens have been maintained in captivity since 1974 but at no stage have they bred. Recently, however, five pregnant females were trapped and gave birth in captivity. Of the five litters, two survived to maturity, two died at ten and 13 days old respectively and one died when three days old. Reported here are observations on the reproduction, postnatal development and maternal care of $M$. varius obtained from the litters as well as from other sources.

\section{MATERIALS AND METHODS}

The pregnant females were caged separately in glass aquaria $(60 \times 30 \times 30 \mathrm{~cm})$ with about $5 \mathrm{~cm}$ of soil in the bottom. Stones were placed at one end as shelter, 
and grass and leaves were given as nesting material. Water was supplied ad libitum and four of the females were fed on mealworms supplemented with fat-free minced oxheart mixed with commercially available muesli. The remaining female was fed a variety of invertebrates (including caterpillars, moths, butterflies, beetles, cockroaches, crickets, spiders and millipedes) as well as rodent and shrew carcases. They were kept indoors at between $20^{\circ} \mathrm{C}$ and $25^{\circ} \mathrm{C}$ with a $12 \mathrm{hr}: 12 \mathrm{hr}$ light: dark regime.

Daily observations were made on the growth and development of the young and on maternal care. These lasted until they were completely weaned in the case of two of the litters. The young were very rarely handled in an attempt to ensure litter survival.

Additional data on reproduction were obtained from the records of the Transvaal Museum, Pretoria.

\section{RESULTS}

$\mathrm{R}$ a u te $\mathrm{nbach}$ (1978) found that the breeding season of $M$. varius occurred between September and March. A post-partum oestrus does occur, as females that are both pregnant and lactating have been trapped in the Transvaal. Specimens from Midmar dam have confirmed this and thus it seems certain that some females will have two or more litters per season.

Of the five litters born in captivity, four consisted of three young each and the remaining one had two. This gives a mean litter size of 2.8 . Trapping records indicate a range from two to five embryos in five pregnant females resulting in a mean of 3.0. If these data are combined, there was an average of 2.9 young in a sample of ten litters. The most common litter size was three and it seems probable that this is the norm.

On their day of birth (Day 0) young $M$. varius weigh approximately $1.0 \mathrm{~g}$ with a head-body length of around $30 \mathrm{~mm}$, tail length of $6 \mathrm{~mm}$ and a hind foot length of $4 \mathrm{~mm}$. They are hairless and blind with their ears closed and their colour pink, with the viscera visible through the ventrum. The umbilical cord is still present, skull sutures are visible and they have short vibrissae $( \pm 3 \mathrm{~mm})$ on the snout. Small toenails are present on fused, fleshy toes. The only audible vocalization from the young is a keening squeak, while the mothers were heard to chitter softly while nursing.

From Day 0 onwards nipple-clinging was apparent. The young were seen attached to the inguinal nipples and were dragged on their backs while the females moved about their cages. From Day 1 to Day 5/6 nipple-clinging appeared obligate and the females were very rarely observed without their young. The clinging was extremely strong and at times when the females were climbing about the rocks in the cages, 
the young were seen to be swinging free, supported only by the nipple. $M$. varius burrows extensively (Goulden \& M e ester, 1978) and once during surface burrowing the mother and nipple-clinging young were completely covered with soil. By Day 6 , clinging was becoming less frequent but still did occur regularly.

The dorsum darkened progressively from Day 0 onwards and the ventrum became less transparent so that by Day 4 the viscera were barely visible. Around Day 6/7 fur was clearly visible and vocalizations had changed to squeaks and twitters. The young were still blind and did not appear to respond to sound. At this point, when nipple-clinging occurred, the young often rolled over and were dragged along on their bellies. From now until about Day 9 they would nipple-cling from their bellies and progressively attempt to run while being dragged.

By Day 10 the coats of most young were complete and the ear structure was more adult-like. At this point, the young would caravan while attached to the nipples. This form of caravanning persisted until Day $13 / 14$ when the young started to change their grip to the rump of the female. All the caravans were "cluster-caravans" (V l a s a k, 1972) and it was only on Day 17 that a "chain-caravan* was seen for the first time.

Around Day 14 most young responded to sound and between Day 15 and 18 their eyes opened. Once this had happened, exploratory behaviour became apparent and caravanning gradually became less common until Day 25 when it ceased altogether.

Weaning started around Day 20 when some young were seen to take mealworms. However, it was only around Day 22 that most were feeding themselves. The last time suckling was observed was on Day 24. At this point the young were approximately $10 \mathrm{~mm}$ shorter than the female in head-body length ( $75-78 \mathrm{~mm}$ vs. $84-87 \mathrm{~mm}$ ).

Lip-licking as described by Stine \& D r y den (1977) was observed between Day 22 and 25 but may well have occurred at other times.

Maternal care in $M$. varius appears to be better developed than in Crocidura flavescens and C. hirta (B a x t e r, 1977). While nipple-clinging predominated, this consisted of simply grooming the young. The mother, after moving about the cage with young attached, would turn around so that she stood over them. Then she would proceed to lick them, particularly the anal region. If one of the young became detached from the nipple during locomotion it emitted a repetitive, high-pitched squeak which would attract the female. She would return to it and stand over it with her body pointing in the opposite direction to that of the young. It would then scrabble its way along her ventrum towards her nipples and she often assisted it by pushing with a forelimb. Once the 
young re-attached, she would move on. At no stage was a female observed to carry her young in her mouth.

Once caravanning commenced, cleaning of the young was essentially the same. However, the litter often detached from their mother and were groomed in whatever position was most convenient.

As the young became more precocious around Day 18, the female often attempted to induce caravanning by biting onto them and pulling them towards her. Initially this was successful but as weaning commenced they showed increasing independence and tended to avoid caravanning. At tirnes when there were disturbances in the cage, such as cage cleaning or feeding, the young would leave the nest to investigate. The mother would follow, attempt to induce caravanning and if successful, lead them back to the nest. If unsuccessful, she often bit onto any convenient part of their body and bodily dragged them back to the nest. Once weaning was complete, the mother made no attempted to induce caravanning.

Both of the litters which survived to weaning lived amicably with their mother thereafter and all nested together. The only mother-young aggression observed was a brief fight over a mealworm on Day 33 .

\section{DISCUSSION}

The breeding season of $M$. varius in the Transvaal as reported by $\mathrm{R}$ a u te $\mathrm{nb}$ a ch (1978) lasts from spring to early autumn, as may be expected. It corresponds well with that of Crocidura hirta (M e e s t e r. 1960) which breeds from September to April and with that of C. flavescens from Natal which breeds from late August to April (B a x te r \& M e e s t e r, in prep.). Other authors, inter alia B or ow s k i \& D e hn el (1952), Clothier (1955), Crowcroft (1957), V lasak (1972) and Fons (1973) also report breeding during the summer months and usually starting in spring and ending in autumn.

The presence of a post-partum oestrus appears to be characteristic of the Soricidae and is reported in six genera; Blarina (B lus, 1971, Cryptotis (C o n a wa y, 1958), Neomys (Price, 1954), Sorex (B r a mbe 11, 1935), Suncus (D ryden, 1969) and Crocidura (Frank, 1953). The genus Myosorex can be added to the list now.

H ell wing (1971) states that the Crocidurinae have smaller litters than the Soricinae. M. varius with a mean litter size of $2.9($ mode=3) conforms to this but appears to have smaller litters than other southern African Crocidurinae which usually have four young (Baxter \& $M$ e e s t e r, in prep.). However, the litter size of $M$. varius does support its inclusion in this subfamily (see B a x t e r et al., 1979).

The most conspicuous behaviour in the postnatal development of $M$. varius is the obligate nipple-clinging of Day 1 to about Day 5 
neonates. Nipple-clinging of this intensity is not reported in any other shrew species although W a l ker $(1968: 155)$ states that "a mother of $S$. (=Sylvisorex) granti has been seen dragging the young about as they clung to her nipples«. Unfortunately, we were unable to find any further information relating to W a l ke r's (loc. cit.) statement and consequently are unable to compare it with what has been seen in M. varius.

Caravanning is characteristic of the Crocidurinae and has been observed in the genera Suncus (D r y d e n, 1968; V o g e 1 1970; F o n s, 1973), Crocidura (inter alia Me ester, 1960; V la sak, 1972, H ellwing, 1973; Grünwald \& Möhres, 1974) and now Myosorex as well. However, Suncus and Crocidura do not nipple-cling.

The transition of nipple-clinging to caravanning described here may possibly indicate the evolution of caravanning. G o u ld (1969) has suggested that caravanning by young Suncus is possibly an extension of suckling. In the case of $M$. varius, with the change from nipple-clinging to nipple-caravanning to rump-caravanning, this suggestion seems valid. The latter form of caravanning is that found in Suncus and Crocidura.

These data suggest that nipple-caravanning arising from nipple-clinging would be the original condition and that rump-caravanning arose from it. In support of this, one finds that Myosorex is regarded as a primitive genus on account of having 32 teeth with seven in the lower jaw (Repenning, 1967). Furthermore, it has affinities with the more primitive subfamily, the Soricinae, through its paired frontal foramina, shape of the braincase and primitive dentition (M e ester, pers. comm.) but it is grouped with the crocidurines on account of unpigmented teeth and continuous articular facets on the mandibular condyle (R e penning, 1967). Consequently, it can be regarded as a primitive crocidurine occupying a systematic position somewhat inbetween the Soricinae and the more advanced crocidurine genera Suncus, Scutisorex, Crocidura and Paracrocidura (Me ester, pers. comm.). These suggestions imply that Suncus and Crocidura have lost the nipple-clinging and nipple-caravanning component from their behavioural repertoire but have retained rump-caravanning. However, on available information, it is not possible to suggest any reason for loss of these behavioural components in the two genera.

There is of course the possibility that caravanning was the original condition and that nipple-clinging arose in response to some selection pressure on $M$. varius, even though it is morphologically primitive. The addition of nipple-clinging to caravanning in the behaviour of a species should increase the chances of survival of the litter. Selection pressure 
favouring smaller litters with a higher survival rate could well resuit in the development of nipple-clinging in addition to caravanning.

$M$. varius does have smaller litters than other southern African crocidurines (B a x ter \& Meester, in prep.) but Dryden (1968) reports a mean litter size of 1.84 in Suncus murinus. However, Lo u c h et al. (1966) report a litter size of 3.8 in the same species. If the latter observation is more accurate, then $M$. varius produces on average the smallest litters of any crocidurine and this is most probably attributable to having nipple-clinging incorporated into its behavioural repertoire. However, it is possible that small litters are a primitive crocidurine characteristic.

On the available information it is not possible to say whether nippleclinging is the condition that preceded the development of caravanning or whether it arose independently. Until further information is available on the reproduction of other Myosorex species, as well as Sylvisorex smallest litters of any crocidurine and this is most probably attributable the significance of nipple-clinging and its relationship to caravanning will remain obscure.

Acknowledgements: We would like to thank the South African Council for Scientific and Industrial Research and the University of Natal for financial support for this study. The Transvaal Museum is thanked for placing its trapping records at the disposal of RMB. Professor J. Meester is thanked for his assistance in preparing the manuscript and for reading and commenting on it.

\section{R.EFERENCES}

1. Baxter R. M., 1977: The biology of captive Crocidura fldvescens with reference to other southern African soricids. M. Sc. thesis, Univ. of Natal, Pietermaritzburg.

2. Baxter R. M., Goulden E. A., \& Meester J., 1979: The activity patterns of Myosorex varius and $M$. cafer in captivity. S. Afr. J. Zool., 14. $91-93$.

3. B a xter R. M., Lloyd C. N. V. \& Davis R. M., (in prep.): Variation in two populations of Myosorex varius ( $\mathrm{S}$ uts, 1832) in South Africa.

4. B a xter R. M. \& M e e ster J., (in prep.): The maintenance and reproduction of some southern African shrews.

5. B1u s L. J. 1971: Reproduction and survival of the short-tailed shrew (Blarina brevicauda) in captivity. Lab. Anim. Sci., 21: 884-891.

6. Borowski S. \& Dehnel A., 1952: Angaben zur Biologie der Soricidae, Annls. Univ. Mariae Curie-Skłodowska, Sect. C, 7: 305-448. [In Polish with German summ.].

7. Brambe 11 F. W. R., 1935: Reproduction in the common shrew (Sorex araneus Linnaeus): I. The oestrus cycle of the female. Phil. Trans. Roy. Soc. Ser. B., 225: $1-49$.

8. C1othier R. R., 1955: Contribution to the life history of Sorex vagrans in Montana. J. Mammal., 36: 214-221. 
9. Conaw y C. H., 1958: Maintenance, reproduction and growth of the least shrew in captivity. J. Mammal., 39: 507-512.

10. Crowcroft P., 1957: The life of the shrew. Max Reinhardt: 1-166. London.

11. Dry den G. L., 1968: Growth and development of Suncus murinus in captivity on Guam. J. Mammal., 49: 51-62.

12. Dryden G. L., 1969: Reproduction in Suncus murinus. J. Reprod. Fert., Suppl., 6: $377-396$.

13. Fons R., 1973: Modalité de la reproduction et développement postnatal en captivité chez Suncus etruscus 'Savi, 1822). Mammalia, 37: 288-324.

14. Frank F., 1953: Beitrag zur Biologie, insbesondere Paarungsbiologie der Feldspitzmaus, (Crocidura leucodon). Bonn. zool. Beitr., 4: 187-194.

15. Gould E., 1969: Communication in three genera of shrews (Soricidae): Suncus, Blarina and Cryptotis. Behav. Sci., Ser. Biol., 3: 11-31.

16. Goulden E. A. \& Meester J., 1978: Notes on the behaviour of Crocidura and Myosorex in captivity. Mammalia, 42: 197-207.

17. Grünwald A. \& Möhres F. P., 1974: Beobachtungen zur Jugendentwicklung und Karawanenbildung bei Weisszahnspitzmäusen (Soricidae Crocidurinae). Z. Säugetierk., 39: 321-337.

18. Heim de Bals a c H. \& Meester J., 1977: Order: Insectivora. [In: Meester J. \& Setzer H. W. (eds), 1971-1977, "The mammals of Africa: an identification manual«] Smithsonian Inst. Publ.: 1-29. Washington D.C.

19. Hellwing S., 1971: Maintenance and reproduction in the white-toothed shrew, Crocidura russula monacha Thomas, in captivity. Z. Säugetierk., 36: 103--113.

20. Hellwing S., 1973: The postnatal development of the white-toothed shrew Crocidura russula monacha in captivity. Z. Säugetierk., 38: 257-270.

21. Louch C. D., Ghosh A. K. \& Pa l B. C., 1966: Seasonal changes in weight and reproductive activity of Suncus murinus in West Bengal, India. J. Mammal., 47: $73-78$.

22. Meester J., 1958: Variation in the shrew genus Myosorex in southern Africa. J. Mamm., 39: 325-339.

23. Meester J., 1960: Shrews in captivity. Afr. Wild Life, 14: 57-63.

24. Price M., 1954: The reproductive cycle of the water shrew, Neomys fodiens bicolor Shaw. Proc. zool. Soc. Lond., 123: 599-621.

25. Rautenbach I. L., 1978: The mammals of the Transvaal. Ph. D. thesis, Univ. of Natal, Pietermaritzburg.

26. Repenning C. A., 1967: Subfamilies and genera of the Soricidae. Prof. Pap. U.S. geol. Surv., 565: 1-74.

27. St in e C. J. \& Dryden G. L., 1977: Lip-licking behaviour in captive musk shrews, Suncus murinus. Behaviour, 62: 298-313.

28. V las a k P., 1972: The biology of reproduction and post-natal development of Crocidura suaveolens Pallas, 1811 under laboratory conditions. Acta Univ. Carol. - Biol., 1970: 207-292.

29. Voge 1 P., 1970: Biologische Beobachtungen an Etruskerspitzmäusen (Suncus etruscus Savi, 1832). Z. Säugetierk., 35: 173-185.

30. Wa $1 \mathrm{k}$ er E. P., 1968: Mammals of the world (2nd ed.) Vol. 1. John Hopkins Press: 1-644. Baltimore.

Accepted, September 14, 1979. 
R. M. BAXTER i C. N. V. LLOYD

\section{ROZROD I ROZWOJ POSTNATALNY MYOSOREX VARIUS}

\section{Streszczenie}

W warunkach laboratoryjnych i z odłowów uzyskano dane o rozrodzie i rozwoju postnatalnym $M$. varius. Sezon rozrodu trwa u tego gatunku od września do marca, samice wykazują ruję poporodową. Srednia wielkość miotu wynosi 3 młode (2-5; średnio 2,9), średni ciężar młodego przy urodzeniu $-1 \mathrm{~g}$, długość ciała - $30 \mathrm{~mm}$. Do piątego dnia życia młode są przyczepione do sutek, a koło 10 dnia zaczynają tworzyć karawanę. Od około 14 dnia po urodzeniu zaczynają reagować na dźwięki, a między 15 a 18 dniem otwierają się im oczy. Karmienie przez matkę trwa do 22-25 dnia. Omawiane jest znaczenie przyczepienia do sutek jako zjawisko poprzedzające tworzenie karawan. 